\title{
Resveratrol inhibits prostaglandin formation in IL-I $\beta$-stimulated SK-N-SH neuronal cells
}

\author{
Lena Wendeburg ${ }^{\dagger 1,2}$, Antonio Carlos Pinheiro de Oliveira ${ }^{\dagger 1}$, \\ Harsharan S Bhatia ${ }^{1}$, Eduardo Candelario-Jalil ${ }^{3}$ and Bernd L Fiebich ${ }^{* 1,2}$
}

Address: ${ }^{1}$ Neurochemistry Research Group, Department of Psychiatry, University of Freiburg Medical School, Hauptstrasse 5, D-79104 Freiburg, Germany, ${ }^{2}$ VivaCell Biotechnology GmbH, Ferdinand-Porsche-Str. 5, D-79211 Denzlingen, Germany and ${ }^{3}$ Department of Neurology, University of New Mexico Health Sciences Center, Albuquerque, NM 87131, USA

Email: Lena Wendeburg - LenaWendeburg@web.de; Antonio Carlos Pinheiro de Oliveira - antoniocpo@yahoo.com.br; Harsharan S Bhatia - harsharan.bhatia@uniklinik-freiburg.de; Eduardo Candelario-Jalil - ecandelario-jalil@salud.unm.edu; Bernd L Fiebich* - bernd.fiebich@uniklinik-freiburg.de

* Corresponding author †Equal contributors

Published: 14 September 2009

Journal of Neuroinflammation 2009, 6:26 doi:10.1 I86/1742-2094-6-26
Received: 22 June 2009

Accepted: 14 September 2009

This article is available from: http://www.jneuroinflammation.com/content/6/1/26

(C) 2009 Wendeburg et al; licensee BioMed Central Ltd.

This is an Open Access article distributed under the terms of the Creative Commons Attribution License (http://creativecommons.org/licenses/by/2.0), which permits unrestricted use, distribution, and reproduction in any medium, provided the original work is properly cited.

\begin{abstract}
Resveratrol, a polyphenol present in grapes and red wine, has been studied due to its vast pharmacological activity. It has been demonstrated that resveratrol inhibits production of inflammatory mediators in different in vitro and in vivo models. Our group recently demonstrated that resveratrol reduced the production of prostaglandin (PG) $E_{2}$ and 8-isoprostane in rat activated microglia. In a microglial-neuronal coculture, resveratrol reduced neuronal death induced by activated microglia. However, less is known about its direct roles in neurons. In the present study, we investigated the effects of resveratrol on interleukin (IL)-I $\beta$ stimulated SK-N-SH cells. Resveratrol (0.I-5 $\mu \mathrm{M}$ ) did not reduce the expression of cyclooxygenase (COX)-2 and microsomal $P E_{2}$ synthase-I (mPGES-I), although it drastically reduced PGE 2 and $P_{\text {GD }}$ content in IL-I $\beta$ stimulated SK-N-SH cells. This effect was due, in part, to a reduction in COX enzymatic activity, mainly COX-2, at lower doses of resveratrol. The production of 8-iso-PGF $2 \alpha$, a marker of cellular free radical generation, was significantly reduced by resveratrol. The present work provides evidence that resveratrol reduces the formation of prostaglandins in neuroblastoma cells by reducing the enzymatic activity of inducible enzymes, such as COX-2, and not the transcription of the PG synthases, as demonstrated elsewhere.
\end{abstract}

\section{Findings}

Neuroinflammation is an important component of neurodegenerative diseases and different inflammatory mediators contribute to the process of these disorders. The prostanoids produced from the arachidonic acid (AA) cascade seem to play important roles in these pathological conditions. Among all prostanoids formed from the AA cascade, prostaglandin (PG) $E_{2}$ seems to play an impor- tant role in the development of neuroinflammation. In inflammatory conditions, the two enzymes that contribute the most to $\mathrm{PGE}_{2}$ production are cyclooxygenase (COX)-2, which converts AA into $\mathrm{PGG}_{2}$ and $\mathrm{PGH}_{2}$, and microsomal $\mathrm{PGE}_{2}$ synthase-1 (mPGES-1), which converts $\mathrm{PGH}_{2}$ into $\mathrm{PGE}_{2}$ [1]. The involvement of $\mathrm{PGE}_{2}, \mathrm{COX}-2$ and mPGES-1 in neurodegenerative diseases has been extensively demonstrated $[2,3]$. 
Resveratrol (trans-3, 5, 4'-trihydroxystilbene) is a polyphenol found in many plants and in the red wine that reveals several pharmacological actions, including antiinflammatory properties. Recent reports have evaluated the potential protective role of resveratrol in neurodegenerative conditions. Resveratrol reduces the expression of different inflammatory mediators involved in the progression of neuropathological conditions and it has been shown to provide neuronal protection in different models [4].

Although resveratrol has been shown to reduce the expression of different inflammatory mediators in some cells, including glial cells, its influence in the production of these molecules in neuronal cells has been less studied. Therefore, in the present study, we investigated the effect of resveratrol on the production of prostanoids induced by IL-1 $\beta$ in SK-N-SH cells, a human neuroblastoma cell line.

SK-N-SH cells were obtained from the American Type Culture Collection (HTB-11, Rockville, USA) and were grown in MEM-Earle's medium (PAA, Cölbe, Germany), which does not contain any anti-inflammatory substance. Medium was supplemented with $5 \%$ fetal calf serum (PAN, Aidenbach, Germany), $2 \mathrm{mM}$ L-glutamine, $1 \mathrm{mM}$ sodium pyruvate, 40 units/ml penicillin/streptomycin (all purchased from PAA Laboratories, Cölbe, Germany), $0.4 \%$ MEM vitamins and $0.4 \%$ MEM nonessential amino acids (both purchased from Invitrogen $\mathrm{GmbH}$, Karlsruhe, Germany). Confluent monolayers were passaged routinely by trypsinization. Cultures were grown at $37^{\circ} \mathrm{C}$ in $5 \% \mathrm{CO}_{2}$ until $80 \%$ confluence, and the medium was changed the day before treatment.

To investigate the effect of resveratrol on the production of inflammatory mediators in neuronal cells, SK-N-SH neuronal cells were pre-incubated with different concentrations $(0.001-5 \mu \mathrm{M})$ of resveratrol (Sigma-Aldrich, Taufkirchen, Germany) for 30 minutes followed by stimulation with IL-1 $\beta(10 \mathrm{U} / \mathrm{ml})$ for $24 \mathrm{~h}$. In control experiments, cells were pre-incubated for $30 \mathrm{~min}$ with the following COX inhibitors: SC-560 (5-(4-chlorophenyl)-1(4-methoxyphenyl)-3-(trifluoromethyl)-1H-pyrazole) (Cayman Chemical Co., Ann Arbor, Michigan, USA), DFU ([5,5-dimethyl-3-(3-fluorophenyl)-4-(4-methylsulphonyl)phenyl-2(5H)-furanone]) and L745,337 ((5-methanesulfonamido-6-(2,4-difluorothiophenyl)-1-

indanone)) (both from Merck Frosst, Montreal, Canada). After the $24 \mathrm{~h}$ stimulation period, supernatants were harvested for the measurement of the levels of 8-iso-PGF $2 \alpha$ (IUPAC nomenclature: $15-\mathrm{F}_{2 \mathrm{t}}-\mathrm{IsoP}$ ), $\mathrm{PGD}_{2}$ (both from Cayman Chemicals, Ann Arbor, MI, USA), and $\mathrm{PGE}_{2}$ (AssayDesign, distributed by Biotrend, Köln, Germany). All measurements were performed according to the man- ufacturer's instructions. The standards were used in the interval of 3.9-500 pg/ml (detection limit of $5 \mathrm{pg} / \mathrm{ml}$ ) for 8-iso- $\mathrm{PGF}_{2 \alpha}$ and $39-2500 \mathrm{pg} / \mathrm{ml}$ (sensitivity of the assay was $36.2 \mathrm{pg} / \mathrm{ml}$ ) for $\mathrm{PGD}_{2}$ and $\mathrm{PGE}_{2}$.

The same stimulation was used for Western blot analysis of mPGES-1, COX-1 and COX-2. For mPGES-1, COX-2 and COX-1 immunoblotting, 30 to $50 \mu \mathrm{g}$ of protein from each sample was subjected to SDS-PAGE (polyacrylamide gel electrophoresis) on a $15 \%$ gel under reducing conditions. Primary antibodies were goat anti-COX-2 and antiCOX-1 (M-19 and M-20, respectively, Santa Cruz, Heidelberg, Germany) diluted 1:500 in Tris-buffered saline (TBS) containing $0.1 \%$ Tween 20 (Merck, Darmstadt, Germany) and $1 \%$ bovine serum albumin (BSA, Sigma), rabbit anti-mPGES-1 (Cayman, 1:500), rabbit anti-actin (Sigma 1:5000).

An AA assay was performed to determine the effect of resveratrol on COX-1 and COX-2 enzymatic activity [5]. To measure total COX activity, SK-N-SH cells were plated in 24 -well cell culture plates and pre-incubated with IL-1 $\beta$ $(10 \mathrm{U} / \mathrm{ml})$ for $24 \mathrm{~h}$ to induce COX-2 protein synthesis. After the pre-incubation, medium was replaced by serumfree medium. Resveratrol was added for $15 \mathrm{~min}$ prior to the addition of AA (15 $\mu \mathrm{M}$ final concentration), which was supplemented for another $15 \mathrm{~min}$. In control experiments, cells were pre-incubated for 15 min with the following COX inhibitors: SC-58125 (1-[(4methysufonyl)phenyl]-3-tri-fluoromethyl-5-(4-fluorophenyl)pyrazole), valeroyl salicylate (VAS) (both compounds obtained from Cayman Chemical Co., Ann Arbor, Michigan, USA) and SC-560. To measure COX-1 activity, the procedure was similar, except that no pre-incubation with IL-1 $\beta$ was performed. Supernatants were collected for determination of $\mathrm{PGE}_{2}$. The procedure to measure COX activity by quantification of the $\mathrm{PGE}_{2}$ production by enzymatic conversion of AA has been widely used and is well accepted as a method to evaluate potential COX inhibitors [6-10]. Since AA is exogenously added, this assay is largely independent of phospholipase activity.

At least three independent experiments were used for data analysis. All the original data were converted into \%-values of IL-1 $\beta$ control and mean \pm S.E.M. were calculated. $\mathrm{IC}_{50}$ (concentration of the resveratrol that inhibited $50 \%$ of the prostaglandin production) was calculated by computerized non-linear regression analysis. Values were compared using one-way ANOVA with post-hoc StudentNewman-Keuls test (multiple comparisons).

Resveratrol did not show toxicity at the doses used as evaluated by the ability of the cells to produce ATP (CellTiterGlo ${ }^{\circledast}$ luminescent cell viability assay kit, Promega, Mannheim, Germany, data not shown). 
Considering that resveratrol possesses antioxidant activity [11], we first evaluated whether resveratrol was able to reduce free radical production in IL-1 $\beta$-stimulated SK-N$\mathrm{SH}$. Isoprostanes are formed from the arachidonate peroxidation catalysed by free radicals [12] and 8-isoprostanes are accepted as a reliable and sensitive measure of free radical formation [13].

IL- $1 \beta$ increased the production of 8 -iso- PGF $_{2 \alpha^{\prime}}$ which was strongly reduced by resveratrol (Fig. 1A), even at very low concentrations $\left(\mathrm{IC}_{50}=0.1337 \mu \mathrm{M}\right)$, confirming its role as a natural antioxidant.

We have recently shown that resveratrol inhibits the production of $\mathrm{PGE}_{2}$ in LPS-stimulated rat microglia [14]. To evaluate whether a similar effect occurs in neuronal cells, we investigated whether resveratrol reduces $\mathrm{PGE}_{2}$ production in IL-1 $\beta$-stimulated SK-N-SH cells. IL-1 $\beta(10 \mathrm{U} / \mathrm{ml})$ strongly induced the production of $\mathrm{PGE}_{2}$ in neuronal cells. The increased $\mathrm{PGE}_{2}$ production at $24 \mathrm{~h}$ was drastically reduced by resveratrol, even at very low doses $\left(\mathrm{IC}_{50}=\right.$ $0.05707 \mu \mathrm{M}$, Fig. 1B). Moreover, resveratrol also strongly reduced the production of $\mathrm{PGD}_{2}\left(\mathrm{IC}_{50}=0.03883 \mu \mathrm{M}\right.$, Fig. 1A). To evaluate whether COX inhibitors were able to reduce the production of $\mathrm{PGE}_{2}$ in the same conditions, we used COX-1 (SC-560) and COX-2 (L745,337 and DFU) inhibitors. Interestingly, both the COX-1 and the COX-2 inhibitors reduced the production of $\mathrm{PGE}_{2}$ in IL-1 $\beta$-stimulated SK-N-SH cells (Fig. 1B), which indicates that COX1 activity may also contribute to the production of prosta-

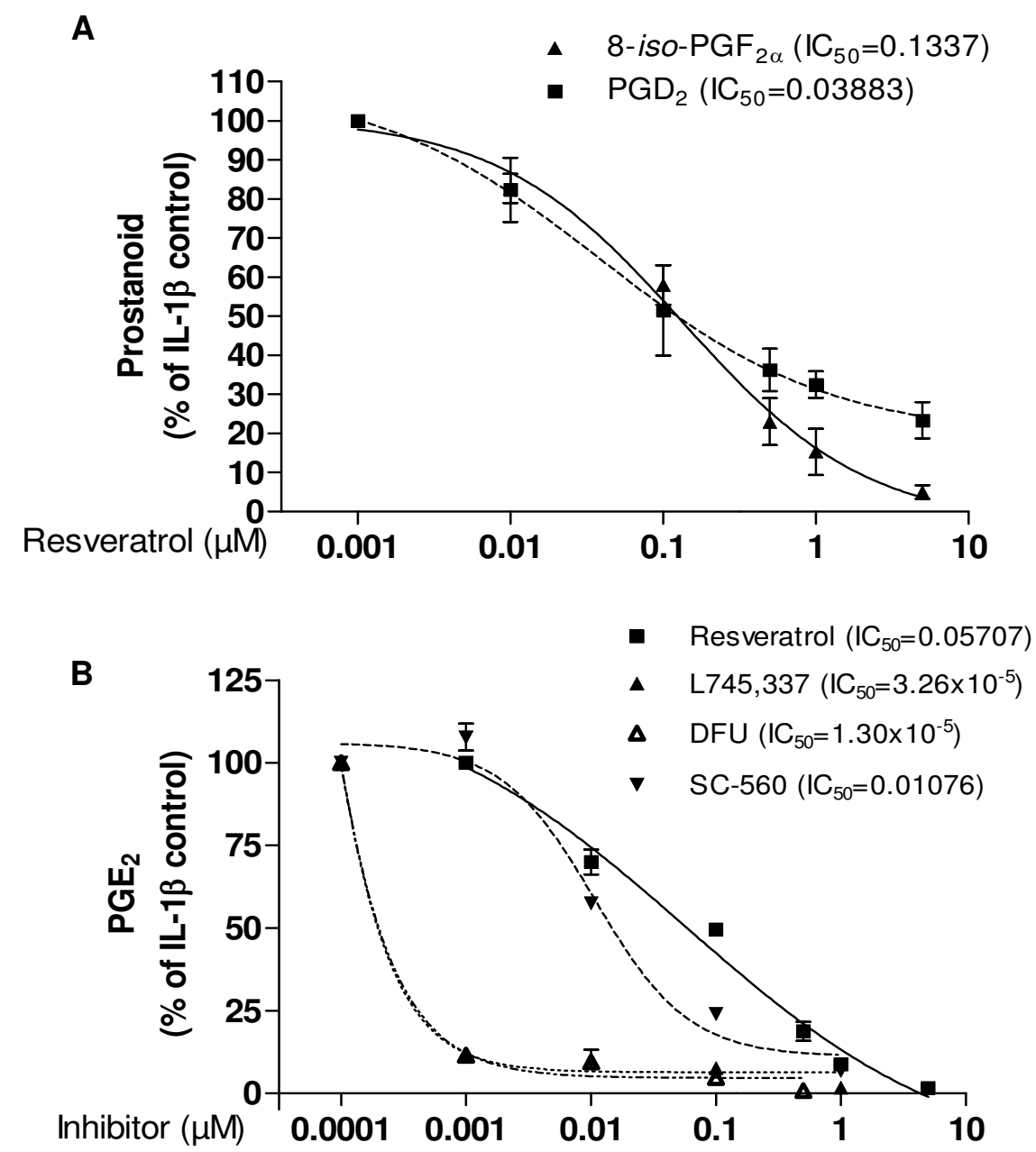

Figure I

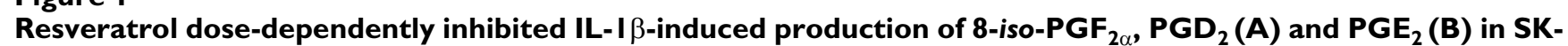
N-SH cells. Selective inhibitors of COX-2 (L745,337 and DFU) and COX-I (SC-560) were included as controls (B). Cells were incubated with the compounds for 30 minutes and subsequently treated with IL-I $\beta$ (I $0 \mathrm{U} / \mathrm{ml})$ for $24 \mathrm{~h}$. Data are expressed as mean \pm S.E.M. of at least 3 independent experiments. 
noids in stimulated cells. Because this experimental set up did not clarify the mechanism of inhibition of the production of prostanoids by resveratrol, we performed further experiments to investigate this issue.

Since $\mathrm{PGE}_{2}$ is produced mainly by COX-2 and mPGES-1 in stimulated cells, we investigated whether the inhibitory effect of resveratrol on $\mathrm{PGE}_{2}$ was due to regulation of the synthesis of these two enzymes. IL- $1 \beta$ increased the protein synthesis of mPGES-1 and COX-2 (Fig. 2A and 2B). Resveratrol, at doses that significantly inhibited $\mathrm{PGE}_{2}$ production, did not significantly reduce mPGES-1 and COX2 immunoreactivities (Fig. 2A and 2B). In addition, COX1 protein also remained unaffected (Fig. 2A).
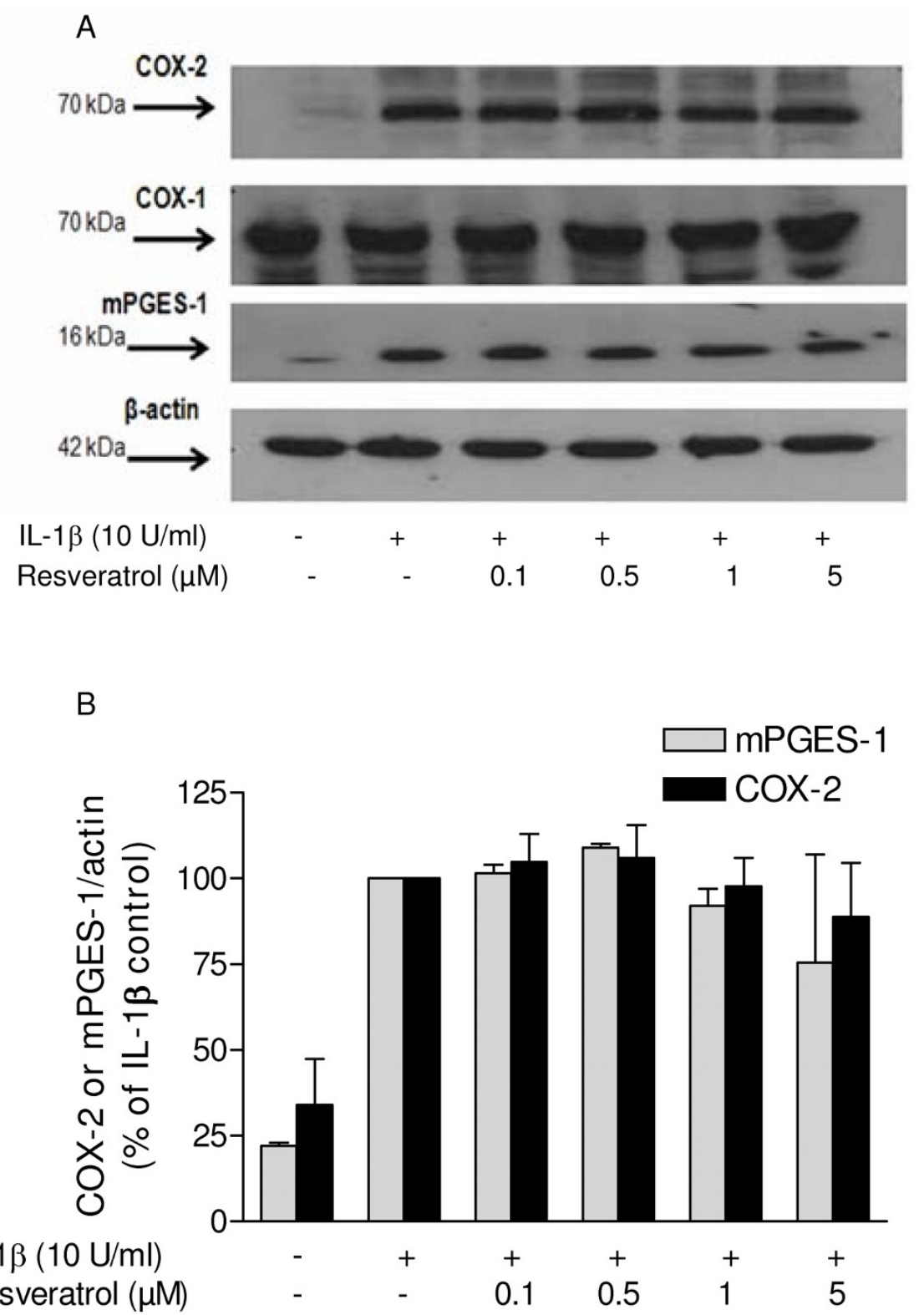

Figure 2

$A$ and B: Immunoblot analysis of the protein levels of mPGES-I, COX-2 and COX-I in IL-I $\beta$-stimulated SK-NSH cells treated with resveratrol. Resveratrol does not inhibit IL-I $\beta$-induced levels of mPGES-I, COX-2 in SK-N-SH cells. Cells were incubated with resveratrol for 30 minutes and subsequently treated with IL-I $\beta$ (I0 U/ml) for $24 \mathrm{~h}$. Data are expressed as mean \pm S.E.M. of at least 3 independent experiments. 
To further clarify the mechanisms responsible for the reduction of $\mathrm{PGE}_{2}$ and $\mathrm{PGD}_{2}$, we investigated whether resveratrol reduces $\mathrm{COX}$ activity. Although resveratrol is a well-known COX-1 inhibitor, it did not inhibit the COX1 activity at the same doses that reduced $\mathrm{PGE}_{2}$ production in SK-N-SH cells (Fig. 3A). A similar effect was obtained with SC-58125 (COX-2 inhibitor), which did not reduce the $\mathrm{PGE}_{2}$ production in this assay (Fig. 3B). On the other hand, SC-560 and VAS (COX-1 inhibitors), strongly reduced $\mathrm{PGE}_{2}$ formation (Fig. 3B).

Although low concentrations of resveratrol did not inhibit COX-1 activity (Fig. 3A), it significantly reduced total COX activity even at low doses (0.01-5 $\mu \mathrm{M})$ as shown in an assay used to test both COX-1 and COX-2 activities (Fig. 3C). A strong reduction of $\mathrm{PGE}_{2}$ was also observed with SC-58125, a COX-2 inhibitor. However, only a par-
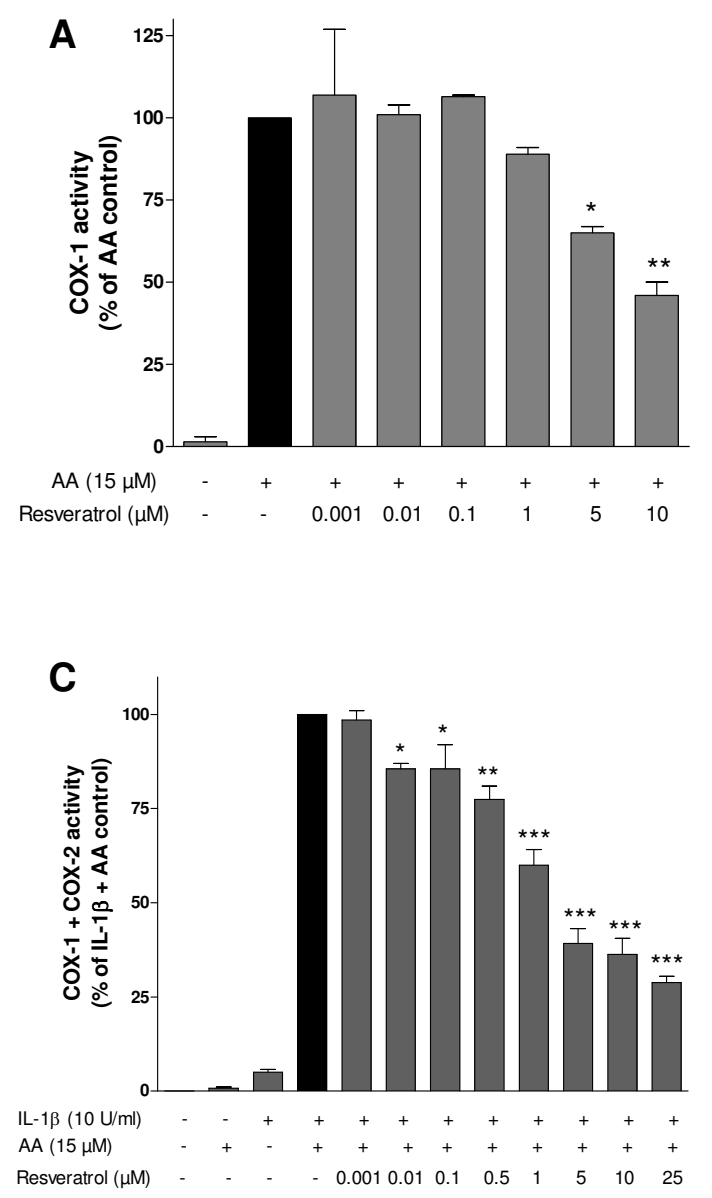

tial reduction in $\mathrm{PGE}_{2}$ content was observed with a high concentration of SC-560 $(10 \mu \mathrm{M})$ and no reduction was observed with VAS, both COX-1 inhibitors (Fig. 3D), confirming our previous results [15]. It is known that the $\mathrm{IC}_{50}$ values for SC-560 are $9 \mathrm{nM}$ and $6.3 \mu \mathrm{M}$ for COX-1 and COX-2, respectively [16]. Therefore, although COX-1 might play a role in this assay, it is possible that at the higher concentration $(10 \mu \mathrm{M})$, SC-560 also partially inhibits $\mathrm{PGE}_{2}$ production by interfering with COX-2 activity. Since at low doses resveratrol did not reduce COX-1 activity (Fig. 3A), inhibition of COX-2 might account for the significant reduction of total COX activity seen at low doses of resveratrol (Fig. 3B).

In the present study, we show that resveratrol, a flavonoid present in some plants and in the red wine, reduced prostanoid synthesis and free radical generation without
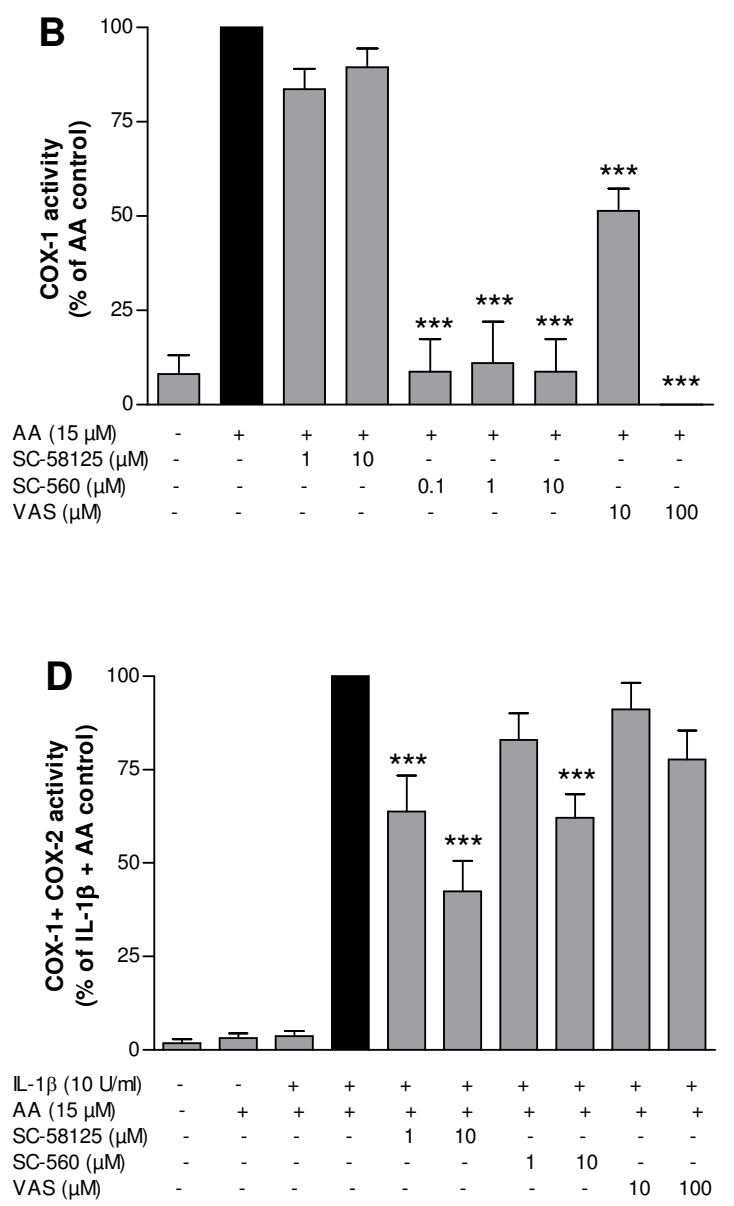

Figure 3

Effect of resveratrol on COX-I (A) and total COX (C) activity in SK-N-SH cells. The arachidonic acid assay was performed as described in the text. Selective inhibitors of COX-I (SC-560 and VAS) and COX-2 (SC-58I25) were included in the COX-I (B) and total COX (D) activity assays to assess the relative contribution of each isozyme to the overall COX enzymatic activity. Data are expressed as mean \pm S.E.M. of at least 3 independent experiments. $*_{p}<0.05$, **p $<0.01$ and $*^{*} * *_{p}<$ $0.00 I$ with respect to IL-I $\beta$ control (One-way ANOVA followed by the Student-Newman-Keuls post-hoc test). 
affecting the expression of COX-2 and mPGES-1 in neuronal cells. This effect may be attributed to the inhibition of COX activity, mainly COX-2, and antioxidant properties.

The search for compounds that have a potential to reduce neuroinflammation has increased exponentially. Resveratrol is in focus for this purpose, because of its plethora of pharmacological effects and since there are evidences suggesting that its metabolites can cross the blood-brain barrier [17-20], although this availability might not be achieved by a dietary administration [21].

The pharmacological properties of resveratrol are of a great interest, since it goes beyond its antioxidant properties. Resveratrol has been shown to reduce the synthesis of iNOS [22] and cytokines [23-25] in different cells. However, just a few papers showed the direct effects of resveratrol on neuronal cells [26-29]. SK-N-SH cells, because of their similarity with primary neuronal cells, are a useful cellular model for studying neuropathological processes that might play a role in neurodegenerative disorders.

Here we demonstrated that resveratrol strongly reduced prostaglandin synthesis without affecting COX-2 and mPGES-1 expression. Recently, using six different human uterine cell lines, Sexton et al. [30] showed that resveratrol, although having opposite effects on COX-2 expression depending on the cell line, reduced $\mathrm{PGE}_{2}$ in almost all cell types tested. On the other hand, resveratrol reduced COX-2 promoter activity and expression and $\mathrm{PGE}_{2}$ production in different cells [31-34]. We also have recently demonstrated that resveratrol reduces mPGES-1 expression, $\mathrm{PGE}_{2}$ and 8 -iso- $\mathrm{PGF}_{2 \alpha}$ generation, without interfering with COX-2 expression in LPS-stimulated microglia [14]. Therefore, the effect of resveratrol on COX-2 and mPGES- 1 expression might be dependent on the cell type.

Similar to our results, resveratrol has been shown to inhibit $\mathrm{PGD}_{2}$ production induced by IgE in bone marrowderived mouse mast cells in vitro [35] and $\mathrm{PGD}_{2}$ and COX-2 expression in the colon in a rat model of chronic colitis [36].

Although resveratrol is known as a COX-1 inhibitor, it did not reduce COX-1 activity at the doses that $\mathrm{PGE}_{2}$ and $\mathrm{PGD}_{2}$ content were reduced. However, COX-2 activity was reduced even at low concentrations that might be important to the reduction of the prostanoids. Other studies have also demonstrated that resveratrol is able to reduce COX-2 activity $[14,33,37,38]$. Although in our experimental set up resveratrol reduced PG formation in the AA assay probably by inhibiting COX-2 activity, it is possible that it reduced the activity of other PGE synthases, such as mPGES-1, even considering that the experimental condi- tions used were not appropriated to measure mPGES-1 activity, which demands glutathione and other reagents [39-41]. Moreover, a reduction in the phospholipase $A_{2}$ activity and AA release might also contribute to the reduction in the prostanoid formation [42].

Resveratrol also diminished isoprostane formation in IL$1 \beta$-stimulated SK-N-SH cells. This ability can be explained by its antioxidant activity and by the reduction of COX-2 activity induced by resveratrol. We and others have demonstrated that 8-iso-PGF $2 \alpha$ formation can also be dependent on COX-2 activity $[13,15,43]$.

Recently, Jin et al. [44] demonstrated that chronic per os administration of resveratrol significantly improved the neurobehavioral deficit and reduced the expression of COX-2 in the substantia nigra in rats administered with 6hydroxydopamine, a substance used to simulate an animal model of Parkinson's disease. Since the COX-2 levels were measured in a brain region, it is not possible to establish its major cellular source, which could be neurons or glial cells. Resveratrol also reduced the apoptotic dopaminergic neuronal death induced by microglia activation in a microglial-neuronal coculture [29]. The neuroprotection conferred by resveratrol might be related to the ability to reduce the production of prostaglandins and free radicals in neurons and microglia.

In summary, we conclude that resveratrol reduced the prostaglandin formation in neuronal cells probably by inhibiting the activity of inducible PG synthesizing enzymes, such as COX-2, but with a weak influence on COX-1 activity and not interfering with the expression of COX-1, COX-2 or mPGES-1. These effects further support the interest of resveratrol as a potential tool in the treatment of neuroinflammatory conditions.

\section{Abbreviations}

ANOVA: analysis of variance; BSA: bovine serum albumin; COX: cyclooxygenase; DMEM: Dulbecco's modified Eagle's medium; EIA: enzyme immunoassay; iNOS: inducible nitric oxide synthase; IL-1 $\beta$ : interleukin- $1 \beta ; 8$ iso- PGF $_{2 \alpha}$ : 8-iso-prostaglandin $\mathrm{F}_{2 \alpha}$; LPS: lipopolysaccharide; mPGES-1: microsomal prostaglandin E synthase 1; PBS: phosphate-buffered saline; PG: prostaglandin; PVDF: polyvinylidene fluoride; SDS: sodium dodecyl sulfate; TBS: Tris-buffered saline; TBST: Tris-buffered saline containing $0.1 \%$ Tween 20 .

\section{Competing interests}

The authors declare that they have no competing interests.

\section{Authors' contributions}

ACPO directed the work, contributed to design the study, reviewed the data and wrote the manuscript; LW per- 
formed Western blot analysis, COX activity assay and prostaglandin measurements; HSB helped in performing prostaglandin measurements and reviewed the manuscript; ECJ provided consultation and reviewed the data and the manuscript; BLF designed the study, reviewed the data and the manuscript. All authors read and approved the final manuscript.

\section{Acknowledgements}

The skillful technical assistance of Ulrike Götzinger-Berger and Brigitte Günter is greatly acknowledged. Antonio Carlos Pinheiro de Oliveira was supported by CAPES (Brasilia/Brazil).

\section{References}

I. Murakami M, Kudo I: Recent advances in molecular biology and physiology of the prostaglandin E2-biosynthetic pathway. Prog Lipid Res 2004, 43:3-35.

2. Chaudhry UA, Zhuang H, Crain BJ, Dore S: Elevated microsomal prostaglandin-E synthase-I in Alzheimer's disease. Alzheimers Dement 2008, 4:6-13.

3. Minghetti L: Cyclooxygenase-2 (COX-2) in inflammatory and degenerative brain diseases. J Neuropathol Exp Neurol 2004, 63:901-910.

4. Anekonda TS: Resveratrol--a boon for treating Alzheimer's disease? Brain Res Rev 2006, 52:316-326.

5. Fiebich BL, Lieb K, Kammerer N, Hull M: Synergistic inhibitory effect of ascorbic acid and acetylsalicylic acid on prostaglandin E2 release in primary rat microglia. J Neurochem 2003, 86: $173-178$.

6. Bosetti F, Rintala J, Seemann R, Rosenberger TA, Contreras MA, Rapoport SI, Chang MC: Chronic lithium downregulates cyclooxygenase-2 activity and prostaglandin $E(2)$ concentration in rat brain. Mol Psychiatry 2002, 7:845-850.

7. Bradbury DA, Corbett L, Knox AJ: PI 3-kinase and MAP kinase regulate bradykinin induced prostaglandin $E(2)$ release in human pulmonary artery by modulating COX-2 activity. FEBS Lett 2004, 560:30-34.

8. Cuendet M, Mesecar AD, DeWitt DL, Pezzuto JM: An ELISA method to measure inhibition of the COX enzymes. Nat Protoc 2006, I:1915-1921.

9. Wu D, Mura C, Beharka AA, Han SN, Paulson KE, Hwang D, Meydani SN: Age-associated increase in PGE2 synthesis and COX activity in murine macrophages is reversed by vitamin $\mathrm{E}$. $\mathrm{Am}$ J Physiol 1998, 275:C66I-668.

10. Zhang MZ, Harris RC, McKanna JA: Regulation of cyclooxygenase-2 (COX-2) in rat renal cortex by adrenal glucocorticoids and mineralocorticoids. Proc Natl Acad Sci USA 1999, 96: 15280-15285.

II. Fremont L: Biological effects of resveratrol. Life Sci 2000, 66:663-673.

12. Morrow JD, Hill KE, Burk RF, Nammour TM, Badr KF, Roberts LJ 2nd: A series of prostaglandin $F 2$-like compounds are produced in vivo in humans by a non-cyclooxygenase, free radical-catalyzed mechanism. Proc Natl Acad Sci USA 1990, 87:9383-9387.

13. Pratico D, Lawson JA, FitzGerald GA: Cyclooxygenase-dependent formation of the isoprostane, 8-epi prostaglandin F2 alpha. J Biol Chem 1995, 270:9800-9808.

14. Candelario-Jalil E, de Oliveira AC, Graf S, Bhatia HS, Hull M, Munoz E, Fiebich BL: Resveratrol potently reduces prostaglandin E2 production and free radical formation in lipopolysaccharideactivated primary rat microglia. J Neuroinflammation 2007, 4:25.

15. Candelario-Jalil E, Akundi RS, Bhatia HS, Lieb K, Appel K, Munoz E, Hull M, Fiebich BL: Ascorbic acid enhances the inhibitory effect of aspirin on neuronal cyclooxygenase-2-mediated prostaglandin E2 production. J Neuroimmunol 2006, I74:39-5I.

16. Smith C), Zhang Y, Koboldt CM, Muhammad J, Zweifel BS, Shaffer A, Talley Jj, Masferrer JL, Seibert K, Isakson PC: Pharmacological analysis of cyclooxygenase- $I$ in inflammation. Proc Natl Acad Sci USA 1998, 95:13313-13318.

17. Baur JA, Sinclair DA: Therapeutic potential of resveratrol: the in vivo evidence. Nat Rev Drug Discov 2006, 5:493-506.
18. Mokni M, Elkahoui S, Limam F, Amri M, Aouani E: Effect of resveratrol on antioxidant enzyme activities in the brain of healthy rat. Neurochem Res 2007, 32:98I-987.

19. Wang Q, Xu J, Rottinghaus GE, Simonyi A, Lubahn D, Sun GY, Sun AY: Resveratrol protects against global cerebral ischemic injury in gerbils. Brain Res 2002, 958:439-447.

20. Pham-Marcou TA, Beloeil H, Sun X, Gentili M, Yaici D, Benoit G, Benhamou D, Mazoit JX: Antinociceptive effect of resveratrol in carrageenan-evoked hyperalgesia in rats: prolonged effect related to COX-2 expression impairment. Pain 2008, 140:274-283.

21. Karuppagounder SS, Pinto JT, Xu H, Chen HL, Beal MF, Gibson GE: Dietary supplementation with resveratrol reduces plaque pathology in a transgenic model of Alzheimer's disease. Neurochem Int 2009, 54: I II-II8.

22. Tsai SH, Lin-Shiau SY, Lin JK: Suppression of nitric oxide synthase and the down-regulation of the activation of NFkappaB in macrophages by resveratrol. $\mathrm{Br} J$ Pharmacol 1999, 1 26:673-680.

23. Gao X, Xu YX, Janakiraman N, Chapman RA, Gautam SC: Immunomodulatory activity of resveratrol: suppression of lymphocyte proliferation, development of cell-mediated cytotoxicity, and cytokine production. Biochem Pharmacol 200I, 62:1299-1308.

24. Marier JF, Chen K, Prince P, Scott G, del Castillo JR, Vachon P: Production of ex vivo lipopolysaccharide-induced tumor necrosis factor-alpha, interleukin-lbeta, and interleukin-6 is suppressed by trans-resveratrol in a concentration-dependent manner. Can J Vet Res 2005, 69: I I I-I 54.

25. Zhong M, Cheng GF, Wang WJ, Guo Y, Zhu XY, Zhang JT: Inhibitory effect of resveratrol on interleukin 6 release by stimulated peritoneal macrophages of mice. Phytomedicine 1999, 6:79-84.

26. Bastianetto $S$, Zheng WH, Quirion R: Neuroprotective abilities of resveratrol and other red wine constituents against nitric oxide-related toxicity in cultured hippocampal neurons. $\mathrm{Br} J$ Pharmacol 2000, 131:71 I-720.

27. Han YS, Zheng WH, Bastianetto S, Chabot JG, Quirion R: Neuroprotective effects of resveratrol against beta-amyloidinduced neurotoxicity in rat hippocampal neurons: involvement of protein kinase C. BrJ Pharmacol 2004, I 4I:997- 1005.

28. Okawara M, Katsuki $H$, Kurimoto E, Shibata $H$, Kume T, Akaike A: Resveratrol protects dopaminergic neurons in midbrain slice culture from multiple insults. Biochem Pharmacol 2007, 73:550-560.

29. Bureau G, Longpre F, Martinoli MG: Resveratrol and quercetin, two natural polyphenols, reduce apoptotic neuronal cell death induced by neuroinflammation. J Neurosci Res 2008, 86:403-4I0.

30. Sexton E, Van Themsche C, LeBlanc K, Parent S, Lemoine P, Asselin $\mathrm{E}$ : Resveratrol interferes with AKT activity and triggers apoptosis in human uterine cancer cells. Mol Cancer 2006, 5:45.

31. Heynekamp JJ, Weber WM, Hunsaker LA, Gonzales AM, Orlando RA, Deck LM, Jagt DL: Substituted trans-stilbenes, including analogues of the natural product resveratrol, inhibit the human tumor necrosis factor alpha-induced activation of transcription factor nuclear factor kappaB. J Med Chem 2006, 49:7182-7|89.

32. Kim YA, Lim SY, Rhee SH, Park KY, Kim CH, Choi BT, Lee SJ, Park YM, Choi YH: Resveratrol inhibits inducible nitric oxide synthase and cyclooxygenase-2 expression in beta-amyloidtreated C6 glioma cells. Int J Mol Med 2006, 17:1069-1075.

33. Subbaramaiah K, Chung WJ, Michaluart P, Telang N, Tanabe T, Inoue $H$, Jang $M$, Pezzuto JM, Dannenberg AJ: Resveratrol inhibits cyclooxygenase-2 transcription and activity in phorbol estertreated human mammary epithelial cells. J Biol Chem 1998, 273:21875-2। 882 .

34. Subbaramaiah K, Michaluart P, Chung WJ, Tanabe T, Telang N, Dannenberg AJ: Resveratrol inhibits cyclooxygenase-2 transcription in human mammary epithelial cells. Ann N Y Acad Sci 1999 , 889:2। 4-223.

35. Baolin L, Inami Y, Tanaka H, Inagaki N, linuma M, Nagai H: Resveratrol inhibits the release of mediators from bone marrowderived mouse mast cells in vitro. Planta Med 2004, 70:305-309.

36. Martin AR, Villegas I, Sanchez-Hidalgo M, de la Lastra CA: The effects of resveratrol, a phytoalexin derived from red wines, 
on chronic inflammation induced in an experimentally induced colitis model. Br J Pharmacol 2006, I 47:873-885.

37. Murias M, Handler N, Erker T, Pleban K, Ecker G, Saiko P, Szekeres $\mathrm{T}$, Jager $\mathrm{W}$ : Resveratrol analogues as selective cyclooxygenase-2 inhibitors: synthesis and structure-activity relationship. Bioorg Med Chem 2004, I 2:557I-5578.

38. Likhitwitayawuid K, Sawasdee K, Kirtikara K: Flavonoids and stilbenoids with COX-I and COX-2 inhibitory activity from Dracaena loureiri. Planta Med 2002, 68:84I-843.

39. Jakobsson PJ, Thoren S, Morgenstern R, Samuelsson B: Identification of human prostaglandin E synthase: a microsomal, glutathione-dependent, inducible enzyme, constituting a potential novel drug target. Proc Natl Acad Sci USA 1999, 96:7220-7225.

40. Mancini JA, Blood K, Guay J, Gordon R, Claveau D, Chan CC, Riendeau $D$ : Cloning, expression, and up-regulation of inducible rat prostaglandin e synthase during lipopolysaccharideinduced pyresis and adjuvant-induced arthritis. J Biol Chem 200I, 276(6):4469-4475.

41. Riendeau D, Aspiotis R, Ethier D, Gareau Y, Grimm EL, Guay J, Guiral S, Juteau H, Mancini JA, Methot N, Rubin J, Friesen RW: Inhibitors of the inducible microsomal prostaglandin E2 synthase (mPGES-I) derived from MK-886. Bioorg Med Chem Lett 2005 I 5:3352-3355.

42. Moreno Jj: Resveratrol modulates arachidonic acid release, prostaglandin synthesis, and 3 T6 fibroblast growth. J Pharmacol Exp Ther 2000, 294:333-338.

43. Akundi RS, Candelario-Jalil E, Hess S, Hull M, Lieb K, Gebicke-Haerter PJ, Fiebich BL: Signal transduction pathways regulating cyclooxygenase-2 in lipopolysaccharide-activated primary rat microglia. Glia 2005, 5 I: 199-208.

44. Jin F, Wu Q, Lu YF, Gong QH, Shi JS: Neuroprotective effect of resveratrol on 6-OHDA-induced Parkinson's disease in rats. Eur J Pharmacol 2008, 600:78-82.

Publish with Bio Med Central and every scientist can read your work free of charge

"BioMed Central will be the most significant development for disseminating the results of biomedical research in our lifetime. "

Sir Paul Nurse, Cancer Research UK

Your research papers will be:

- available free of charge to the entire biomedical community

- peer reviewed and published immediately upon acceptance

- cited in PubMed and archived on PubMed Central

- yours - you keep the copyright
BioMedcentral 